\section{Barriers and facilitators to bicycle use in adults: a systematic review}

\section{Barreiras e facilitadores para o uso de bicicleta em adultos: uma revisão sistemática}

\author{
Edina Maria de Camargo ${ }^{1,2,3}$ \\ Rogério César Fermino ${ }^{2,4,5}$ \\ Rodrigo Siqueira Reis ${ }^{1,2,3}$
}

\section{ABSTRACT}

The aim of this systematic review was to summarize the evidence on the barriers and facilitators to the use of bicycles in adults. Search terms were defined and was searched in the following databases: Lilacs, SciELO, PubMed, Web of Science and Science Direct. A total of seven studies met the inclusion criteria and showed that the main barriers and facilitators to the use of bicycles are related to the physical, social and natural environment characteristics and individual characteristics (cognitive, psychological and emotional aspects). Interventions in the area of public health should consider these features to increase the use of bicycles in adults.

\section{KEYWORDS}

Motor Activity; Leisure Activities; Bicycling; Locomotion; Epidemiologic Studies; CrossSectional Studies.

\section{RESUMO}

O objetivo desta revisão sistemática foi sintetizar as evidências sobre as barreiras e os facilitadores para o uso de bicicleta em adultos. Foram utilizados termos de busca para localizar as evidências nas bases Lilacs, SciELO, PubMed, Web of Science e Science Direct. Sete estudos atenderam os critérios de inclusão e mostraram que as principais barreiras e facilitadores para o uso da bicicleta guardam relação com características do ambiente físico, social e natural, além de características individuais e aspectos cognitivos, psicológicos e emocionais. Intervenções na área da saúde pública poderiam considerar estas características para aumentar o uso de bicicleta em adultos.

\section{PALAVRAS-CHAVE}

Atividade motora; Atividades de lazer; Ciclismo; Locomoção; Estudos Epidemiológicos; Estudos Transversais
Rev Bras Ativ Fís Saúde p. 103-112

DOI

http://dx.doi.org/10.12820/rbafs.v.20n2p103

1 Pontifícia Universidade Católica do Paraná, Escola de Saúde e Biociências, Curso de Educação Física, Brasil.

2 Pontifícia Universidade Católica do Paraná, Grupo de Pesquisa em Atividade Física e Qualidade de Vida (GPAQ/PUCPR), Brasil.

3 Universidade Federal do Paraná, Programa de Pós-Graduação em Educação Física, Brasil.

4 Universidade Tecnológica Federal do Paraná, Departamento Acadêmico de Educação Física, Brasil

5 Universidade Tecnológica Federal do Paraná, Grupo de Pesquisa em Fisiologia, Atividade Física e Saúde, Brasil 


\section{INTRODUCTION}

Evidence indicates that the use of bicycles can contribute to sustainability in great urban centers and that it is associated with positive population health aspects $^{1}$, such as the reduction in mortality of all causes and cancer in middle-aged adults and the elderly ${ }^{2}$. Consequently, encouraging bicycle use for transportation and leisure can be an important strategy for health promotion ${ }^{3-5}$.

Despite the potential benefits, the number of individuals who use bicycles regularly is still small ${ }^{6,7}$. There is little evidence in low- and middle-income countries, but this use seems to be low when compared to high-income countries $^{5,6,8,9}$. In Brazil, for example, a population-based study conducted in the city of Pelotas showed a prevalence of bicycle use among a population of workers of $17.2 \%{ }^{8}$. In another study conducted in the city of Curitiba, Southern Brazil, $11 \%$ and $17 \%$ of the population used bicycles for transportation and leisure, respectively ${ }^{6}$, whereas high-income countries revealed significantly higher values (26 and $41 \%$, respectively) ${ }^{5,9,10}$.

Several urban form and structure characteristics (presence of bike paths/ lanes, traffic density and sloped streets) and public transport characteristics (distance to destination and ease of movement ${ }^{3,11}$ ) are associated with bicycle use, which can partly explain the difference in levels of use in different countries. However, individual aspects such as the reasons that can hinder (barriers) or promote (facilitators) bicycle use may also explain these differences ${ }^{12}$.

Some barriers have been reported in the literature, such as the low level of safety associated with crime and traffic, low access to bike paths ${ }^{5}$ and infrastructure (bicycle parking, locker rooms etc.), lack of a companion and closeness to destinations ${ }^{5}$. Barriers and facilitators to bicycle use can vary according to sex, age and cultural aspects of the populations from different countries ${ }^{5,12,13}$. Few studies have simultaneously analyzed the barriers and facilitators to bicycle use in adults in a single research project ${ }^{11}$, hindering the full understanding of these characteristics in one population exclusively.

The identification of such characteristics facilitates the understanding of the factors that interfere with this behavior. These factors are important for managers to develop specific interventions aiming to increase bicycle use in the population ${ }^{12,14,15}$. As a result, the objective of this review study was to summarize the evidence on barriers and facilitators to bicycle use in adults.

\section{METHODS}

\section{Search strategy and evidence inclusion and exclusion criteria}

The review followed the methodological procedures described in the literature ${ }^{11,16,17}$ and was performed in periodicals reviewed by peers and indexed in the following electronic databases: Lilacs, SciELO, PubMed, Web of Science and Science Direct. These databases include evidence in the areas of health, transport engineering, architecture and urbanism.

The only studies included were qualitative and quantitative empirical studies that showed reports on the barriers and facilitators to bicycle use in adults. This alternative was selected after the exploratory analysis of evidence, as there was only a small number of studies including distinct methods, which would prevent the development of the systematic review. The search was 
restricted to studies performed in human beings from 2000 onwards. This time restriction is suggested in the literature as the starting point of evidence about the relevance that bicycle use can have on one's lifestyle ${ }^{18}$. Review and opinion-based articles, letters to the editors, books, book chapters, research reports, dissertations and theses were excluded from the analysis. The English language was not an exclusion factor for the search for articles. The aim was to include all studies found.

The search ended in November 2014 and it included the following descriptors in Portuguese and English: "cycling", "bicycle", "barriers", "perceived barriers" and "facilitators", with the "AND" and "OR" Boolean operator combination ${ }^{11,17}$. The search terms were standardized in Portuguese and subsequently used in the Lilacs and SciELO databases. The corresponding terms in English, were used in the PubMed, Web of Science and Science Direct databases.

The syntaxes with the terms, descriptors and Boolean operators used in the review included the following combinations: (cycling OR bicycle) AND (barriers OR perceived barriers OR facilitators) in English; and (ciclismo OR bicicleta) AND (barreiras OR percepção de barreiras OR facilitadores) in Portuguese.

\section{Selection of articles}

The first stage of the review consisted of searching for references in the indexed databases $(n=305)$ and excluding titles repeated among these databases ( $\mathrm{n}=52,17 \%$ ) (figure 1). Next, the titles of the 253 studies (100\%) were read, of which $226(89 \%)$ were excluded as they did not meet the inclusion criteria established. In the following stage, after the abstracts of 27 potentially eligible studies were read, 20 (8\%) were excluded for not being associated with the theme (for example, barriers to bicycle helmet use). Finally, seven studies $(3 \%)$ were fully analyzed, as they met the inclusion criteria and were selected for the review, analysis and detailed description (figure 1). Additionally, the gray literature was searched, when the lists of references to the articles included were checked. However, no other studies were included in the review as a result of this search.

\section{Data gathering}

After the selection and reading of studies, data on authors, country, state/city, characteristics of participants (sex, age group etc.), number of participants, purpose of bicycle use (leisure or transportation), research approach and respective reports of barriers and facilitators were obtained. Data were gathered in duplicate (pairs).

\section{RESULTS}

\section{Overall study characteristics}

The studies included in the analysis ( $\mathrm{n}=7$ ) were published between 2007 and 2014. A total of three studies were performed in the USA (42.9\%), two in Australia (28.5\%), one in Holland (14.3\%) and one in Brazil (14.3\%) (Table 1). The population investigated was comprised of parents and their schoolchildren (two studies, 28.6\%, the studies on parents and children were included as they had reports on parental barriers); workers who use bicycles (one study 


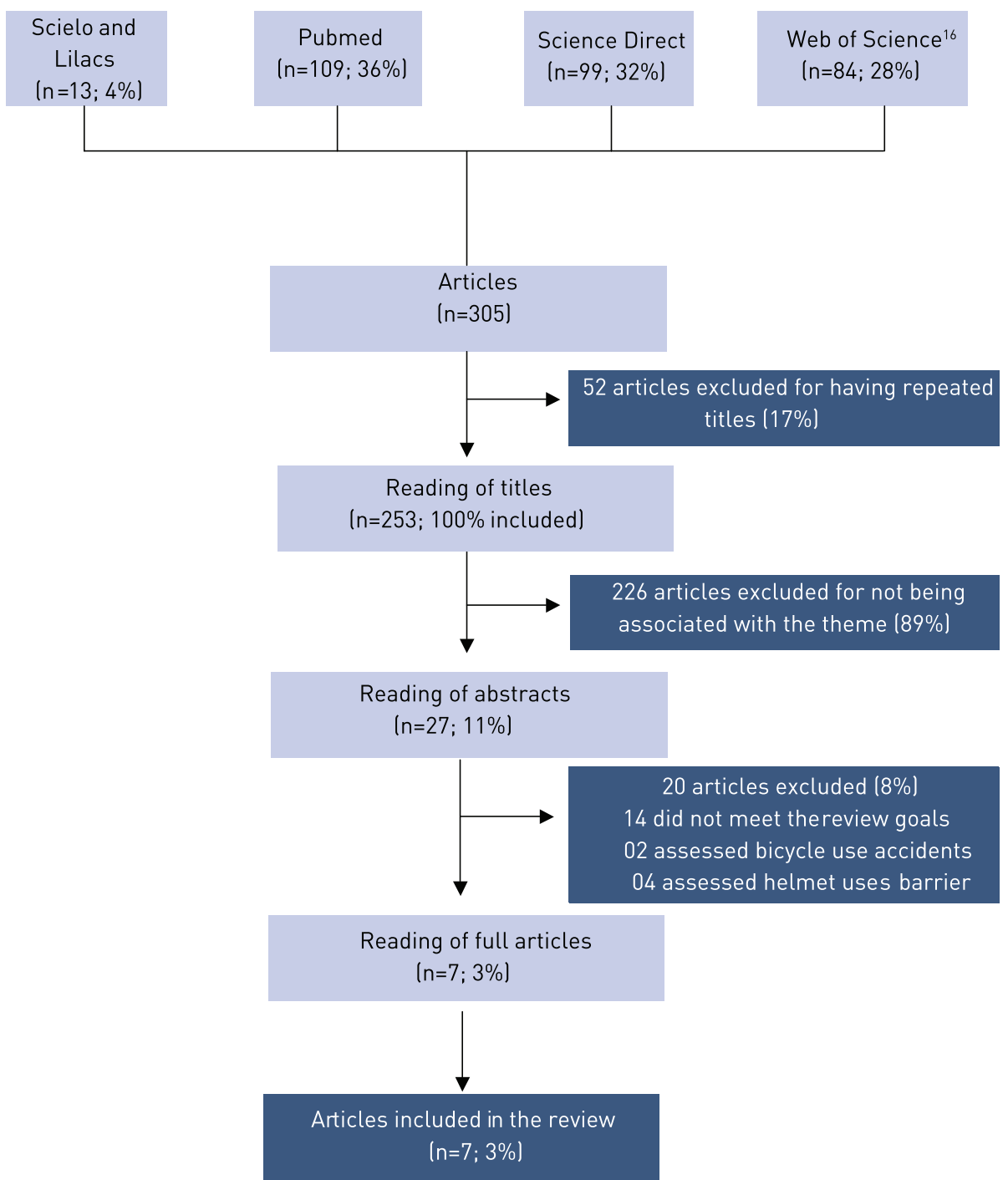

FIGURE 1 - Flow chart of the search, selection and exclusion of the studies used in this review.

- $14.2 \%$ ), and users and non-users of bicycles (four studies - 57.1\%). A total of five qualitative studies conducted interviews with focus groups (71.4\%) and two quantitative studies used face-to-face interviews and online questionnaires $(28.6 \%)$. Barriers and facilitators to bicycle use were investigated during leisure time (four studies - 57.1\%) and transportation (seven studies - 100\%) (Table 1).

\section{Barriers to bicycle use}

The barriers reported are related to the physical environment (inadequate streets, difficulty to rent bicycles, bike paths, easy access to other means of transport, locker rooms, bicycle parking, distance to destinations, sloped streets), social environment (crime, fear of kidnapping, fear of riding alone, parental concern, children's immature judgment, danger, fear of children being involved in accidents, heavy and aggressive traffic, lack of police protection at school crossings, bad driver behavior, heavy traffic, verbal aggression by drivers, lack of a companion, lack of family support, lack of support from friends, lack of government support, bullying by peers, lack of awareness in general, lack of environmental awareness, cleanliness, presence of dogs), nat- 
ural environment (rain, cold, heat, snow, wind, lack of natural lighting), in addition to individual characteristics (many materials/objects to carry, excessive planning involved, financial conditions) and cognitive, psychological and emotional aspects (low self-efficacy) (Table 2).

TABLE 1 - Characteristics of the studies included in this review on barriers and facilitators to bicycle use in adults (n=7).

\begin{tabular}{|c|c|c|c|c|c|c|c|c|c|}
\hline $\begin{array}{l}\text { Author } \\
\text { lyear)ref }\end{array}$ & Country & City/state & Sex & $\begin{array}{l}\text { Characteristics } \\
\text { of participants }\end{array}$ & $\mathrm{n}$ & Bicycle use & $\begin{array}{l}\text { Research } \\
\text { approach }\end{array}$ & $\begin{array}{l}\text { Data } \\
\text { collection }\end{array}$ & $\begin{array}{l}\text { What was } \\
\text { assessed }\end{array}$ \\
\hline $\begin{array}{l}\text { Ahlport et } \\
\text { al }(2007)^{20}\end{array}$ & USA & $\begin{array}{l}\text { North } \\
\text { Carolina }\end{array}$ & $\begin{array}{l}\text { Male } \\
\text { and } \\
\text { female }\end{array}$ & $\begin{array}{l}\text { Parents and } \\
\text { schoolchildren }\end{array}$ & $\begin{array}{l}37 \text { parents } \\
\text { and } 37 \\
\text { schoolchildren } \\
\text { (50\% females) }\end{array}$ & Transportation & Qualitative & Focus groups & $\begin{array}{l}\text { Barriers and } \\
\text { facilitators }\end{array}$ \\
\hline $\begin{array}{l}\text { Forman et } \\
\text { al }(2008)^{22}\end{array}$ & USA & $\begin{array}{l}\text { Boston, } \\
\text { San Diego, } \\
\text { Cincinnati. }\end{array}$ & $\begin{array}{l}\text { Male } \\
\text { and } \\
\text { female }\end{array}$ & $\begin{array}{l}\text { Parents and } \\
\text { schoolchildren }\end{array}$ & $\begin{array}{l}289 \text { parents and } \\
189 \text { adolescents } \\
\text { (82\% females) }\end{array}$ & $\begin{array}{l}\text { Transportation } \\
\text { and leisure }\end{array}$ & Quantitative & $\begin{array}{l}\text { Face-to-face } \\
\text { questionnaire }\end{array}$ & Barriers \\
\hline $\begin{array}{l}\text { Engbers } \\
\text { et al } \\
(2010)^{5}\end{array}$ & Holland & Leiden & $\begin{array}{l}\text { Male } \\
\text { and } \\
\text { female }\end{array}$ & Workers & $\begin{array}{l}799 \text { workers } \\
\text { who use } \\
\text { bicycles (50\% } \\
\text { females) }\end{array}$ & Transportation & Quantitative & $\begin{array}{l}\text { Online } \\
\text { questionnaire }\end{array}$ & $\begin{array}{l}\text { Barriers and } \\
\text { facilitators }\end{array}$ \\
\hline $\begin{array}{l}\text { Daley et al } \\
(2011)^{24}\end{array}$ & Australia & Sidney & $\begin{array}{l}\text { Male } \\
\text { and } \\
\text { female }\end{array}$ & $\begin{array}{l}\text { Bicycle users } \\
\text { and non-users }\end{array}$ & $\begin{array}{l}70 \text { bicycle users } \\
\text { and non-users } \\
\text { (66\% females) }\end{array}$ & $\begin{array}{l}\text { Transportation } \\
\text { and leisure }\end{array}$ & Qualitative & Focus groups & $\begin{array}{l}\text { Barriers and } \\
\text { facilitators }\end{array}$ \\
\hline $\begin{array}{l}\text { Fishman } \\
\text { et al } \\
(2012)^{18}\end{array}$ & Australia & Brisbane & Male & $\begin{array}{l}\text { Bicycle users } \\
\text { and non-users }\end{array}$ & $\begin{array}{l}\text { Cyclists, non- } \\
\text { cyclists and City } \\
\text { Cycle users* }\end{array}$ & $\begin{array}{l}\text { Transportation } \\
\text { and leisure }\end{array}$ & Qualitative & Focus groups & $\begin{array}{l}\text { Barriers and } \\
\text { facilitators }\end{array}$ \\
\hline $\begin{array}{l}\text { Spencer } \\
\text { et al } \\
(2013)^{21}\end{array}$ & USA & Vermont & $\begin{array}{l}\text { Male } \\
\text { and } \\
\text { female }\end{array}$ & Workers & $\begin{array}{l}24 \text { bicycle } \\
\text { users for } \\
\text { transportation } \\
\text { (29\% females) }\end{array}$ & Transportation & Qualitative & Focus groups & Barriers \\
\hline $\begin{array}{l}\text { Camargo } \\
\text { et al } \\
(2014)^{12}\end{array}$ & Brazil & Curitiba & $\begin{array}{l}\text { Male } \\
\text { and } \\
\text { female }\end{array}$ & $\begin{array}{l}\text { Adults who use } \\
\text { bicycles for } \\
\text { transportation } \\
\text { and leisure } \\
\text { and who are } \\
\text { activists }\end{array}$ & $\begin{array}{l}48 \text { ( } 12 \text { users for } \\
\text { transportation, } \\
12 \text { users in } \\
\text { their leisure } \\
\text { time, and } 24 \\
\text { activists) }\end{array}$ & $\begin{array}{l}\text { Transportation } \\
\text { and leisure }\end{array}$ & $\begin{array}{l}\text { Qualitative } \\
\text { and } \\
\text { quantitative }\end{array}$ & Focus groups & $\begin{array}{l}\text { Barriers and } \\
\text { facilitators }\end{array}$ \\
\hline
\end{tabular}

${ }^{*}$ City Cycle: Bicycle rental locations in Brisbane, Australia

\section{Facilitators to bicycle use}

The facilitators reported are associated with the physical environment (adequate streets, bicycle parking with an opening and closing time, number and quality of bike paths, presence of bicycle parking at the companies, better infrastructure, bicycle racks, showers, locker rooms and parking, convenient traffic, presence of police officers at crossings, convenience for bicycle use, closeness of school; living close to the workplace, reducing the transportation time compared to other means of transport, fewer delays due to traffic, better time management/schedule), social environment (traffic awareness, presence of a companion, presence of someone to accompany the children, encouragement among siblings, family support, support from friends, government support, social status, culture, safety, notification system that delivers a text message when children arrive at their destination, incentive from employers for infrastructure maintenance, subsidies for mileage, promotion and marketing of the theme), cognitive, psychological and emotional aspects (incentive for exercising, meeting the physical activity recommendation, health perception, a clean, healthy and happy environmental image, well-being, contact with nature, environmental awareness) (Table 2). 
TABLE 2 - Barriers and facilitators to bicycle use from the studies included in the review according to type of research.

\begin{tabular}{|c|c|c|}
\hline Author (year) ref & Barriers & Facilitators \\
\hline \multicolumn{3}{|c|}{ Qualitative research - focus groups } \\
\hline $\begin{array}{l}\text { Ahlport et al } \\
(2007)^{20}\end{array}$ & $\begin{array}{l}\text { Barriers perceived by parents: fear of kidnapping, fear of } \\
\text { children riding alone, parental concern, fear of children } \\
\text { being involved with accidents, child misjudgment, bullying } \\
\text { from peers. } \\
\text { Environmental characteristics: lack of adequate streets, } \\
\text { weather (rain, cold), distance to destinations (school, } \\
\text { market, church), slopes, heavy and aggressive traffic. } \\
\text { School characteristics: lack of police protection lat school } \\
\text { and school crossings) }\end{array}$ & $\begin{array}{l}\text { Facilitators perceived by parents: child may be accompanied } \\
\text { by someone, notification system (text messages, calls) } \\
\text { letting them know when their children arrive at a certain } \\
\text { destination, support from siblings, time management/ } \\
\text { flexible schedule, convenient traffic, incentive for exercising, } \\
\text { perception of health benefits. } \\
\text { Environmental characteristics: adequate streets, closeness } \\
\text { to school, suitable weather. } \\
\text { School characteristics: Police protection at crossings, heavy } \\
\text { traffic (children do not like to remain seated in the car in traffic } \\
\text { thus encouraging them to ride a bicycle with their parents, it is } \\
\text { more convenient to ride a bicycle than being in traffic). }\end{array}$ \\
\hline Daley et al $(2011)^{24}$ & $\begin{array}{l}\text { Image of cycling: dangerous, not serious. } \\
\text { Image of cyclists: criminal offenders. }\end{array}$ & $\begin{array}{l}\text { Image of cycling: environmentally friendly, clean, healthy and "happy". } \\
\text { Image of cyclists: culture, social status. }\end{array}$ \\
\hline $\begin{array}{l}\text { Fishman et al } \\
(2012)^{18}\end{array}$ & $\begin{array}{l}\text { Accessibility: credit cards cannot be used for bicycle } \\
\text { rentals, helmets are mandatory, small number of bike } \\
\text { rental locations in the city. } \\
\text { Safety: lack of infrastructure for bicycles, driver behavior. } \\
\text { Weather: heat, rain. } \\
\text { Street characteristics: slopes and "hills". }\end{array}$ & $\begin{array}{l}\text { Accessibility: promotion, marketing of the theme, opening/ } \\
\text { closing bike parking times. }\end{array}$ \\
\hline $\begin{array}{l}\text { Spencer et al } \\
(2013)^{21}\end{array}$ & $\begin{array}{l}\text { Weather: unpleasant temperature (cold), rain, ice, snow } \\
\text { and strong winds (making it harder to keep one's balance } \\
\text { on a bicycle) } \\
\text { Lighting: lack of natural lighting due to seasonal climate } \\
\text { variations. } \\
\text { Road conditions: roads are cleaned due to winter (snow), } \\
\text { lack of adequate infrastructure (bike paths). }\end{array}$ & N.A. \\
\hline $\begin{array}{l}\text { Camargo et al } \\
(2014)^{12}\end{array}$ & 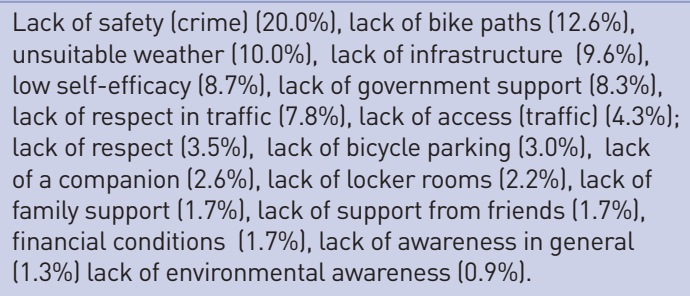 & $\begin{array}{l}\text { Well-being }(20.6 \%) \text {, adequate infrastructure }(10.6 \%) \text {, family } \\
\text { support }(10.6 \%) \text {, presence of a companion }(10.0 \%) \text {, high } \\
\text { self-efficacy }(7.1 \%) \text {, contact with nature }(5.9 \%) \text {, support } \\
\text { from a companion (5.3\%), presence of bicycle parking } \\
(5.3 \%) \text {, safety from crime }(4.7 \%) \text {, presence of access (traffic) } \\
(4.1 \%) \text {, environmental awareness }(4.1 \%) \text {, presence of locker } \\
\text { rooms }(2.9 \%) \text {, support from friends }(2.4 \%) \text {, distance }(2.4 \%) \text {, } \\
\text { presence of bike paths }(2.4 \%) \text { and government support } \\
(1.8 \%) \text {. }\end{array}$ \\
\hline \multicolumn{3}{|c|}{ Quantitative studies - questionnaire } \\
\hline $\begin{array}{l}\text { Forman et al } \\
(2008)^{22}\end{array}$ & $\begin{array}{l}\text { A total of } 17 \text { barriers to three destinations (stores, schools } \\
\text { and parks) were assessed: many slopes, lack of bike paths } \\
\text { and lighting on the way, heavy traffic, dangerous crossings, } \\
\text { distance, uninteresting route, lack of a companion, } \\
\text { weather (heat), large number of materials/objects to carry, } \\
\text { more convenient means of transport, excessive planning } \\
\text { involved, lack of safety, victim of verbal aggression, lack of } \\
\text { bicycle parking, presence of dogs on the way. } \\
\text { The most frequently mentioned aspects were: heavy } \\
\text { traffic, dangerous crossings, more convenient means of } \\
\text { transport and lack of safety. }\end{array}$ & N. A. \\
\hline $\begin{array}{l}\text { Engbers et al } \\
(2010)^{5}\end{array}$ & $\begin{array}{l}\text { Non-bicycle users: great distance between home and the } \\
\text { workplace }(41 \%) \text {, perspiration }(30 \%) \text {, excessive time spent } \\
(23 \%) .\end{array}$ & $\begin{array}{l}\text { Bicycle users: exercising while using it as a means of } \\
\text { transport ( } 54 \%) \text {, health benefits }(54 \%) \text {, meeting physical } \\
\text { activity requirements ( } 31 \%) \text {, the number and quality of bike } \\
\text { paths }(16 \%) \text {, presence of bicycle parking at the company } \\
(13 \%) \text {, fewer delays due to traffic }(12 \%) \text {, greater support from } \\
\text { employer (infrastructure maintenance, subsidies for mileage } \\
\text { - both } 11 \%) \text {, appealing routes ( } 11 \%) \text {, better infrastructure } \\
\text { (bicycle racks; shows and locker rooms }(7 \%) \text {, paid parking } \\
(5 \%) \text { accessibility from the workplace }(4 \%) \text { and location ( } 4 \%) \\
\text { Non-bicycle users: living close to the workplace }(39 \%) \text {, short } \\
\text { time of transportation compared to other means of transport } \\
(20 \%) \text { and presence of a companion }(14 \%)\end{array}$ \\
\hline
\end{tabular}

N.A.: data not available 


\section{DISCUSSION}

The objective of this review was to synthesize the evidence on barriers and facilitators to bicycle use among adults. This behavior has been recently associated with health promotion and quality of life in high-income countries ${ }^{5}$. However, there had been no studies synthesizing data on barriers and facilitators to bicycle use until now. The relevance of this information is related to the possibility of developing strategies to solve or alleviate the problems reported by bicycle users, apart from strengthening the aspects that can promote its use $\mathrm{e}^{9,10,12,14}$.

Only seven studies met the inclusion criteria for the review: all of them had been recently published and six had been performed in high-income countries. These characteristics emphasize the current concern about bicycle use in urban centers, in addition to identifying the lack of studies performed in low- and middle-income countries such as those in Latin America ${ }^{11,19}$. For example, a recent review of the factors associated with bicycle use in adults identified 29 studies on this theme, of which only two had been conducted in Latin America ${ }^{11}$.

In general, the barriers more frequently reported are associated with the physical $^{12,18,20-22}$, natural ${ }^{12,18,20-22}$ and social environments ${ }^{12,20}$, individual characteristics $^{12,22}$ and psychological aspects ${ }^{12}$. In truth, these characteristics can hinder bicycle use in both leisure time and transportation. However, the literature only shows a consistent association between lack of infrastructure, sloped streets and distance to destinations and bicycle use ${ }^{11}$. As an example, a study conducted with Australian adults showed that the presence of bike paths in a certain district can increase the probability of bicycle use in transportation $^{10}$ by $77 \%$, apart from the inverse association found between distance to destinations and presence of sloped streets in a district and bicycle use ${ }^{23}$. These results are supported by reports found in qualitative studies included in the present review. As an example, in the study performed by Fishman et al. ${ }^{18}$, participants reported that "...living far away from the workplace is a barrier... which leads to other barriers... you sweat a lot... you need time to take a shower when arriving at the workplace and, to do this, you need locker rooms at the company...". Additionally, participants reported that "...the lack of infrastructure is one of the main problems, in addition to the behavior of motor vebicle drivers..."18.

However, reports on barriers associated with infrastructure were also found. In a Brazilian study ${ }^{12}$, participants reported that "...without a bike path and safety, it's bard to use a bicycle. I often stopped because of fear". Similar reports were found in qualitative ${ }^{20}$ and quantitative studies ${ }^{22}$ performed in the USA, where street characteristics were also mentioned ${ }^{20}$ : “...streets are not suitable, which makes it harder" ${ }^{\prime 2}$. Although these reasons are frequently reported, other barriers are relevant and depend on the climatic aspects of one's home country, such as general weather conditions, snow and rain $^{21}$. Individuals reported that "....temperatures below $10^{\circ} \mathrm{F}\left(-12^{\circ} \mathrm{C}\right)$ are unpleasant, as the fingers freeze..." as well as "...road conditions do not take bicycles into account, snow is shoved towards the edge of streets and so it completely covers bike paths or partly covers them, leaving a very narrow space..." 21 .

In contrast, facilitators are associated with the physical ${ }^{5,12,24}$ and social environment $^{12,20}$, apart from psychological, cognitive and emotional aspects ${ }^{18}$. 
In fact, the literature reports a consistent association between perception of health benefits and social support and bicycle use ${ }^{11}$. As an example, in one of the studies ${ }^{12}$, individuals reported that "...I feel well, I feel I'm taking care of my health and I'm happy to feel the wind blowing on my face and the sense of freedom...”, “...I began using a bicycle after I got married, because my husband encouraged me..."12. Similar reports were also found in quantitative studies ${ }^{5,25,26}$. In fact, Titze et al. ${ }^{23}$ observed that the social support of a spouse can increase the probability of bicycle use in transportation by $62 \%$. Moreover, another study reported the relevance of support from parents and siblings, so as to encourage bicycle use for the active transportation of children to school: "... the support from siblings is important... as they study at the same school, they can also go together... they don't like to be stuck in traffic (in a car), they prefer to ride a bike, they like when we ride with them as this is encouraging..." ${ }^{20}$. This aspect is emphasized by reports found in the study conducted by Camargo et al ${ }^{12}$, where participants reported that "...I had a hard time when I was a teenager, because my parents wouldn't let me go out on the streets to ride a bike. Now, I'm free and independent..." ${ }^{12}$.

There were some study limitations that should be pointed out to better understand the results. The small number of studies (seven) prevents this theme to be approached from a broader perspective. A total of five studies used the focus group method, including in-depth data on the main reports, although their results can hardly be generalized. However, only two studies ${ }^{5,22}$ used the quantitative approach with a representative sample and described the main barriers, despite their not testing the association between these barriers and bicycle use. It was not possible to apply an instrument to determine the study quality score. As the studies here included followed different methodological aspects, the application of a single instrument could produce inaccurate scores, which would result in the misjudgment of these studies and affect the quality of the conclusions.

It could be concluded that the barriers and facilitators to bicycle use are associated with physical, social and natural environment characteristics, apart from individual characteristics and cognitive, psychological and emotional aspects.

Public health interventions could take these characteristics into consideration to promote bicycle use in adults. Aspects associated with the improvement in infrastructure for bicycles (number, quality and connectivity of bike paths and lanes), public safety (police protection, crime reduction), respect in traffic (campaigns to raise the awareness of drivers and better law enforcement) and campaigns to promote bicycle use (associated with companionship and support from family and friends) could all be actions aimed at increasing bicycle use in the population. The City Departments of Urban Mobility, Transport and Traffic, Public Safety and Urbanism are fundamental to enable changes to be put into practice.

Future studies should assess the possible impact that interventions based on environmental changes (safety, infrastructure etc.) can have on bicycle use. The triangulation of different research methods and approaches (representative surveys, focus groups and surveillance and identification of the number of bicycle users) needs to be used, so that relevant gaps regarding factors associated with bicycle use can be understood. 


\section{Author contributions}

E. M. de Camargo was responsible for the study design, search, reading, assessment and gathering of data from articles and initial manuscript writing; R. C. Fermino was responsible for the reading, assessment and gathering of data from articles, manuscript writing and critical review in all its stages; and R. S. Reis was responsible for the study design and manuscript critical review.

\section{REFERENCES}

1. De Hartog JJ, Boogaard H, Nijland H, Hoek G. Do the health benefits of cycling outweigh the risks? Environ Health Persp. 2010;118(8):1109-16

2. Oja P, Titze S, Bauman A, Geus B, Krenn P, Reger-Nash B et al. Health benefits of cycling: a systematic review. Scand J Med Sci Sports. 2011;21(4):496-509.

3. Becerra JM, Reis RS, Frank LD, Ramirez-Ramerro FA, Welle B, Arriaga Cordero E, et al. Transport and health: a look at three Latin American cities. Cad de Saúde Pública. 2013;29(4):654-66.

4. Evenson KR, Aytur SA, Satinsky SB, Rodríguez DA. Barriers to municipal planning for pedestrians and bicyclists in North Carolina. N C Medical Journal. 2011;72-74(2):8998.

5. Engbers LH, Hendriksen IJM. Characteristics of a population of commuter cyclists in the Netherlands: perceived barriers and facilitators in the personal, social and physical environment. Int J Behav Nutr Phys Act. 2010;7 (5):89-93.

6. Kienteka M, Reis RS, Rech CR. Personal and behavioral factors associated with bicycling in adults from Curitiba, Parana State, Brazil. Cad Saúde Pública. 2014;30(1):79-87.

7. Reis RS, Hino AA, Parra DC, Hallal PC, Brownson RC. Association of perceived environmental and personal factors with bicycling and walking for transportation in residents of three Brazilian cities Am J Prev Med. 2013;44 (2):9-17.

8. Bacchieri G, Gigante DP, Assunção MC. Determinantes e padrões de utilização da bicicleta e acidentes de trânsito sofridos por ciclistas trabalhadores da cidade de Pelotas, Rio Grande do Sul, Brasil. Cad Saúde Publica 2005;21:1499-508.

9. Titze S, Stronegger WJ, Janschitz S, Oja P. Association of built-environment, socialenvironment and personal factors with bicycling as a mode of transportation among Austrian city dwellers. Am J Prev Med. 2008;47(3):252-59.

10. Titze S, Giles-Corti B, Knuiman MW, Pikora TJ, Timperio A, Bull FC Associations between intrapersonal and neighborhood environmental characteristics and cycling for transport and recreation in adults: baseline results from the reside study. J Phys Act Health. 2010;7(4):423-31.

11. Kienteka M, Fermino RC, Reis RS. Fatores individuais e ambientais associados com o uso de bicicleta por adultos: uma revisão sistemática. Rev. Bras. Ativ.Fís Saúde. 2014;19(1):14-26.

12. Camargo EM, Fermino RC, Añez CRR, Reis RS. Barriers and facilitators to bicycle use for transport and leisure among adults. Rev Bras Ativ Fis Saúde. 2014;19(2):257-65.

13. Reichert FF, Barros AJ, Domingues MR, Hallal PC. The role of perceived personal barriers to engagement in leisure-time physical activity. Am J Public Health. 2007;97(3):515-19

14. Mosquera J, Parra DC, Gomez L, Sarmiento O, Schmid T, Jacoby E. An Inside Look at Active Transportation in Bogotá: A Qualitative Study.J Phys Act Health. 2012;9(9):77685.

15. Sarmiento OL, Torres A, Jacoby E, Pratt M, Schmid TL, Stierling G. The CiclovíaRecreativa: A mass-recreational program with public health potential. J Phys Act Health 2010;7(2):S163-S80.

16. Jackson N, Waters E. Criteria for the systematic review of health promotion and public health interventions. Health Promotion. 2005;20(4):367-74

17. Fermino R, Reis R. Variáveis individuais, ambientais e sociais associadas com o uso de espaços públicos abertos para a prática de atividade física: uma revisão sistemática. Rev Bras Ativ Fís Saúde. 2014;18(5):523-35 
18. Fishman E, Washington S, Haworth N. Barriers and facilitators to public bicycle scheme use: A qualitative approach. Trans. Res. Pt. F-Traffic Psychol. Behav. 2012;15(6):68698.

19. Hoehner CM, Ribeiro IC, Parra DC, Reis RS, Azevedo MR, Hino AA, et al. Physical activity interventions in Latin America: expanding and classifying the evidence. Am J Prev Med. 2013;44(3):e31-e40.

20. Ahlport KN, Linnan L, Vaughn A, Evenson KR, Ward DS. Barriers to and facilitators of walking and bicycling to school: Formative results from the non-motorized travel study. Health Educ Behav 2008;35(2):221-44.

21. Spencer P, Watts R, Vivanco L, Flynn B. The effect of environmental factors on bicycle commuters in Vermont: influences of a northern climate. Journal of Transport Geography. 2013;31:11-17.

22. Forman H, Kerr J, Norman GJ, et al. Reliability and validity of destination-specific barriers to walking and cycling for youth. Am J Prev Med. 2008;46(4):311-16.

23. Titze S, Stronegger WJ, Janschitz S, Oja P. Environmental, social, and personal correlates of cycling for transportation in a student population. J Phys Act Health. 2007;4(1):66-79.

24. Daley M, Rissel C. Perspectives and images of cycling as a barrier or facilitator of cycling. Transport Policy. 2011;18(1):211-16.

25. Huy C, Becker S, Gomolinsky U, Klein T, Thiel A. Health, medical risk factors, and bicycle use in everyday life in the over-50 population. J Aging \& Phys Activ. 2008;16(4) 454-64

26. Heinen E, Maat K, Wee Bv. The role of attitudes toward characteristics of bicycle commuting on the choice to cycle to work over various distances. Transport Res D-TR E 16. 2011;16(2):102-09.

CORRESPONDING AUTHOR

EDINA MARIA DE CAMARGO

Pontifícia Universidade Católica do

Paraná - PUCPR

Escola de Saúde e Biociências (ESB) -

Curso de Educação Física

Grupo de Pesquisa em Atividade Física

e Qualidade de Vida - GPAQ

Rua Imaculada Conceição, 1155

Curitiba - PR - BRAZIL

80215-901

Fone: +55-41-9121-6197 / +55-41-

3271-2503

E-mail: edina.camargolapucpr.br 